\title{
Effect of Age and Environment on Strength of Old Baked Clay Bricks of Indus Valley Civilization
}

\author{
NAWAB ALI LAKHO*, MUHAMMAD AUCHAR ZARDARI*, AND ASHFAQUE AHMED PATHAN**
}

RECEIVED ON 25.01.2016 ACCEPTED ON 11.05.2016

\begin{abstract}
This paper presents results of experimental investigations conducted on old baked clay bricks of Indus Valley civilization of tenth century. The object of this study is to evaluate the effect of age and environmental conditions on the strength of the baked clay bricks which are about 1000 years old. The brick samples were collected from six different archeological sites at the banks of old route of River Indus in district Sanghar, Sindh, Pakistan. These specimens were tested for apparent density, compressive strength, tensile strength, modulus of rupture and the weathering effects on them during the course of time. ASTM (American Society for Testing and Materials) standard for baked clay bricks, based on compressive strength, suggests that the bricks of four sites can withstand severe weathering while the bricks of two sites are resistant to moderate weathering. These results were compared to the values of the corresponding data of bricks, of same period, obtained from the historical monuments of the world as reported in the literature. The comparison showed that the values of physical properties of old baked clay bricks of Indus valley civilization of tenth century are in agreement with that of old baked clay bricks of contemporary era. The results of this study could also be helpful for preservation of old archeological sites of Indus valley civilization.
\end{abstract}

Key Words: Baked Clay, Compressive Strength, Old Bricks, Indus Valley Civilization, Apparent Density, Effect of Age.

\section{INTRODUCTION}

$\mathrm{B}$ rick has remained a fundamental material of building construction in the history of civilizations. The historical buildings and monuments constructed throughout the evolution of civilizations are mainly made of brick and stone masonry. Brick masonry is one of the ancient and most reliable methods of construction used by people throughout the ages. It is still commonly used in modern buildings [1]. The study of old baked clay bricks reveals that physical, chemical and mechanical properties of these bricks show scattered values. The values of apparent density, and compressive strength of old baked clay bricks vary from $1500-1800 \mathrm{~kg} / \mathrm{m}^{3}$ and $1.5-50 \mathrm{MPa}$, respectively [1].

Brick is an artificial metamorphic rock [2] and is prone to weathering and disintegration due to atmospheric and environmental effects with time, and results in less compressive strength if not baked and compacted properly

* Assistant Professor, Department of Civil Engineering, Quaid-e-Awam University of Engineering, Science \& Technology, Nawabshah. ** Assistant Professor, Department of Civil Engineering, Mehran University of Engineering \& Technology, Jamshoro. 
[3-9]. To preserve masonry historical buildings and monuments [10-17], much care is needed nowadays because of high content of ChloroFlouro Carbon in atmosphere which can deteriorate baked clay bricks in short time [18]. The moisture content and the salts present in the bricks and the surroundings where these bricks are buried is also a governing factor for weathering of these bricks [19-20].

In Pakistan, there are a number of masonry buildings and archeological sites which represent its cultural heritage and national identity. Therefore, it is necessary to save these monuments of brick masonry to preserve them in their original shape and condition against such environmental and weathering effects. Thus, it is important to study the effect of age and environment on the bricks through its service life. In order to get insight of the environmental and weathering effect on old baked clay bricks, such bricks were collected from six ruined sites of Indus valley in District Sanghar, Sindh, Pakistan, on the banks of river Indus. These sites were destroyed by an earthquake that occurred in $975 \mathrm{AD}$ [21]. The object of this study is to determine physical properties of old baked clay bricks such as apparent density, compressive strength, tensile strength, modulus of rupture and effect of weathering on these bricks with time.

\section{MATERIALS AND METHOD}

To study structural behaviour and resistance to weathering of historical baked clay bricks of Indus valley, the baked clay bricks were collected from six different ruined sites of district Sanghar, Sindh, Pakistan (Figs. 13 ). These sites are on the banks of old route of river Indus. Of these four were human settlements while other two were grave yards situated near these sites. These sites lie within a circle of $2 \mathrm{~km}$ radius. The description and Global Position of these sites is given in Table 1.

\subsection{Test Specimens}

To determine compressive strength, tensile strength, modulus of rupture, apparent density and water absorption ratio, three brick specimens were collected from each site and tests were conducted to determine above structural properties. Each of the following specimen was cut from each brick: (i) $50 \mathrm{~mm}$ Cubes, (ii) briquettes having neck section equal to $25 \times 25 \mathrm{~mm}$ (iii) small beam section $50 \times 50 \times 225 \mathrm{~mm}$.

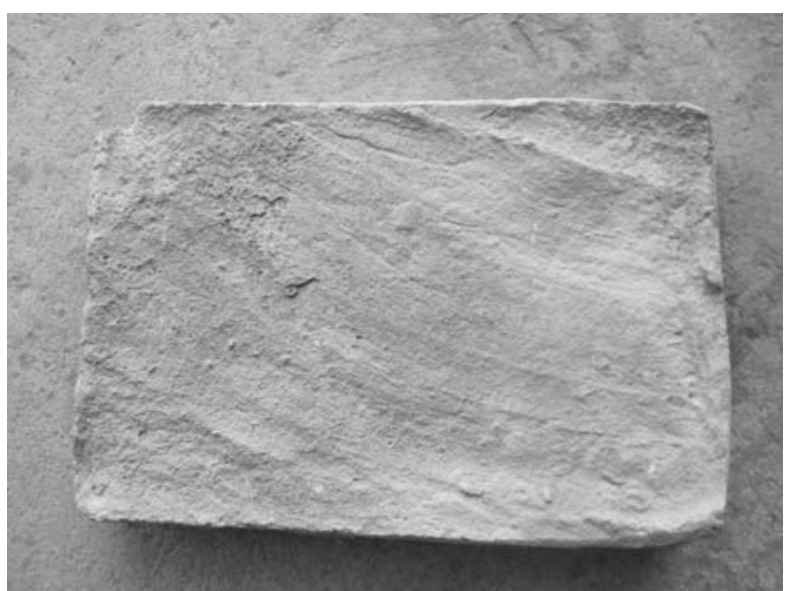

FIG. 1. BAKED CLAY BRICK COLLECTED FROM JARKUS

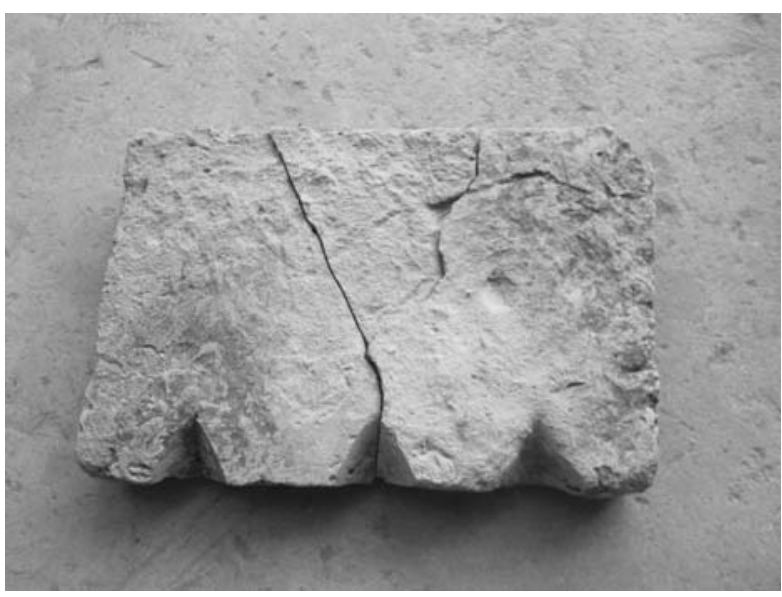

FIG. 2. BAKED CLAY BRICK COLLECTED FROM DAIM PIR

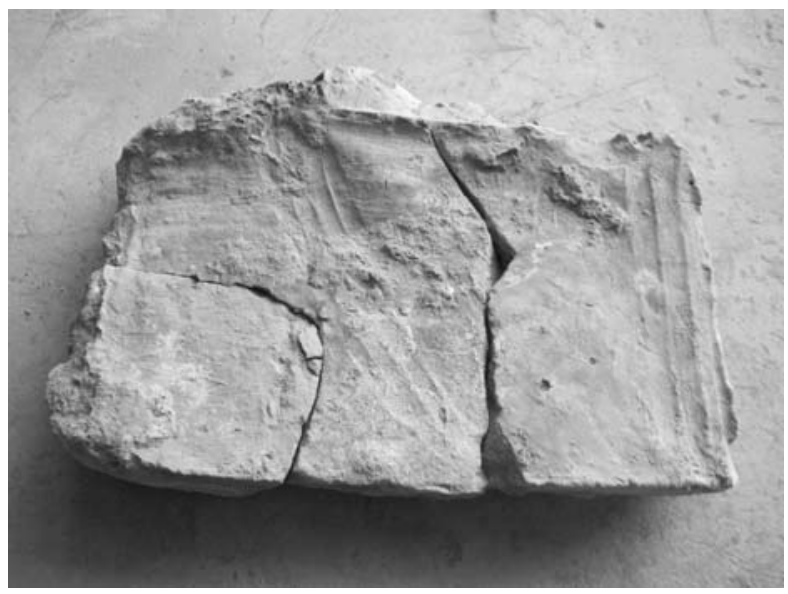

FIG. 3. BAKED CLAY BRICK COLLECTED FROM BARA HAZARI

Mehran University Research Journal of Engineering \& Technology, Volume 35, No. 3, July, 2016 [p-ISSN: 0254-7821, e-ISSN: 2413-7219] 


\subsubsection{Tensile Strength}

Tensile strength of old baked clay bricks was determined by cutting one briquette from each baked clay brick. The size of briquettes was $76 \times 44 \mathrm{~mm}$ and having neck section equal to $25 \mathrm{~mm}$ (Fig. 4). These briquettes were tested in briquettes testing machine (Fig. 5).

\subsubsection{Compressive Strength}

Cubes of 50mm size were cut from each baked clay brick and tested for compression in UTM (Universal Testing Machine) (Figs. 6-7).

\subsubsection{Modulus of Rupture and Apparent Density}

Small beam specimens having size of 50×50×225mm were sawed form each brick to determine modulus of rupture and apparent density. These plain beam specimens were tested in flexure by applying point load at mid-span of the beam.

\subsubsection{Water Absorption Ratio}

The brick specimens were oven dried at $110^{\circ} \mathrm{C}$ for 24 hours and were immersed in water at room temperature. After 24 hours, the beam specimens were taken out of water and after wiping off the surface of bricks with a cloth, weight was taken within five minutes.

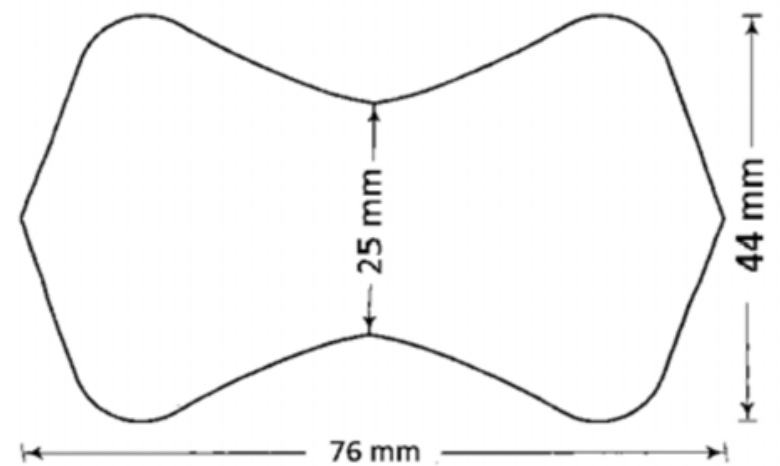

FIG. 4. PLAN OF BRIQUETTE FOR TENSION TEST OF OLD BAKED CLAY BRICKS

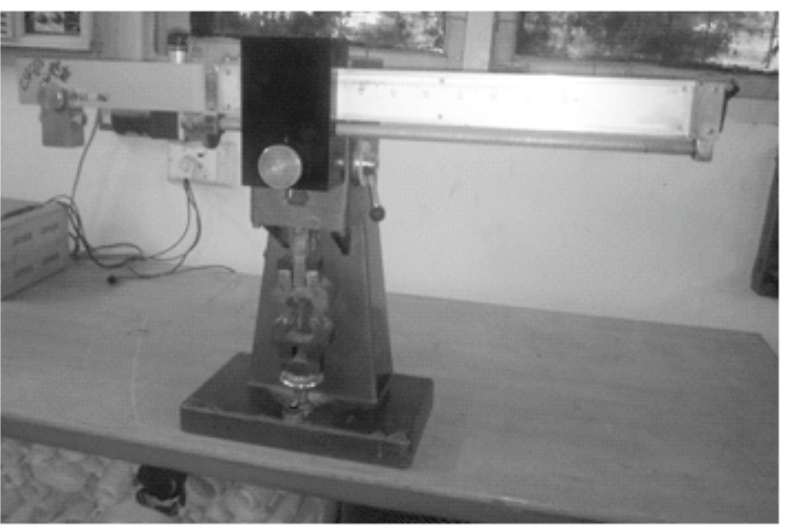

FIG. 5. BRIQUETTE TESTING MACHINE

TABLE 1. DESCRIPTION OF SITES AND THEIR GLOBAL POSITION

\begin{tabular}{|c|c|c|c|c|c|}
\hline No. & Local Name of Site & Type of Site & $\begin{array}{l}\text { Area of Site } \\
\quad \text { (acres) }\end{array}$ & River Bank & $\begin{array}{l}\text { Global Position } \\
\text { (deg) }\end{array}$ \\
\hline 1. & Lanjari & Town & 16 & Right & $\begin{array}{l}255137 \mathrm{~N} \\
682945 \mathrm{~S}\end{array}$ \\
\hline 2. & Jarkus & Town & 11 & Right & $\begin{array}{r}255103 \mathrm{~N} \\
683016 \mathrm{~S}\end{array}$ \\
\hline 3. & Daim Pir & Grave yard & 5 & Right & $\begin{array}{r}255020 \mathrm{~N} \\
683036 \mathrm{~S}\end{array}$ \\
\hline 4. & Bara Hazari & Big town & 42 & Left & $\begin{array}{l}255035 \mathrm{~N} \\
683146 \mathrm{~N}\end{array}$ \\
\hline 5. & Jadam Pir & Grave yard & 3 & Left & $\begin{array}{l}255005 \mathrm{~N} \\
683051 \mathrm{~S} \\
\end{array}$ \\
\hline 6. & Ghoghat & Town & 36 & Right & $\begin{array}{l}254959 \mathrm{~N} \\
683022 \mathrm{~S}\end{array}$ \\
\hline
\end{tabular}

Mehran University Research Journal of Engineering \& Technology, Volume 35, No. 3, July, 2016 [p-ISSN: 0254-7821, e-ISSN: 2413-7219] 


\section{RESULTS AND DISCUSSION}

These bricks were investigated for apparent density, compressive strength, tensile strength, and modulus of rupture, water absorption and the effect of weathering. The results are given in Table 2.

The results of compressive strength of old baked clay bricks of Indus valley civilization of tenth century were

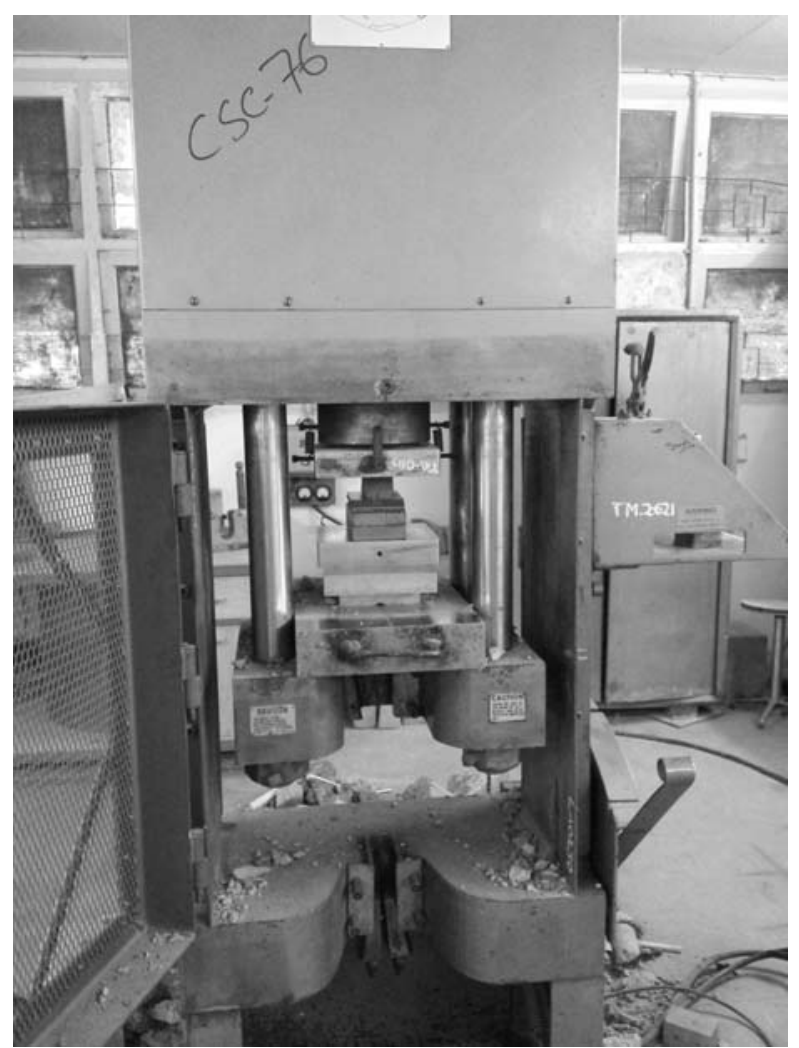

FIG. 6. TESTING OF CUBE CUT FROM BAKED CLAY BRICK IN UNIVERSAL TESTING MACHINE compared with that of bricks of contemporary era. The comparison shows that the values of compressive strength of four sites are more than the reported value of compressive strength, and values of two sites (i.e. Lanjari and Jarkus) are less than that of reported [22].

The values of apparent density of baked clay bricks of Indus valley civilization when compared to the reported values of the same era, show that the values of three sites (Lanjari, Jarkus and Bara Hazari) of Indus valley are in agreement with the reported values while the values of other three sites (Daim Pir, Jadam Pir and Ghoghat) are more than the reported ones [23-24].

The values of tensile strength of old baked clay bricks of Indus valley civilization of tenth century were compared with the corresponding values of modern baked clay bricks

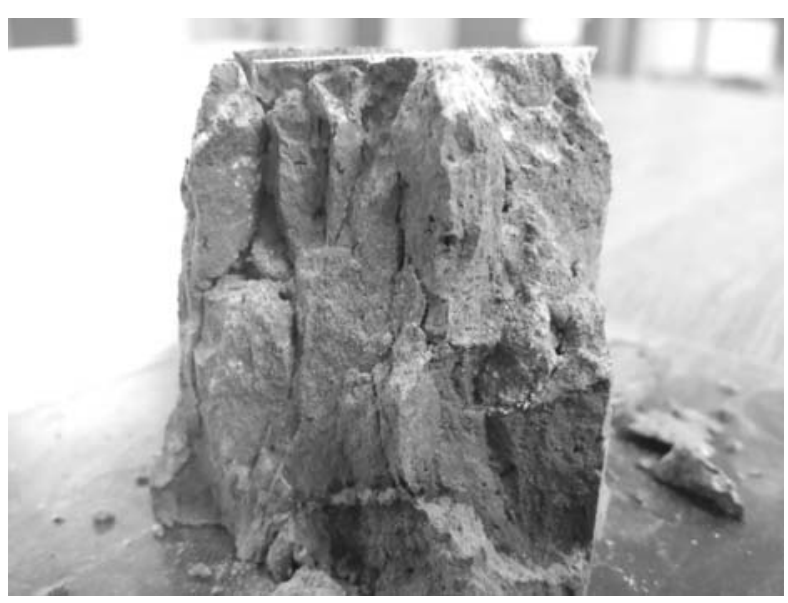

FIG. 7. CUBE CUT FROM BAKED CLAY BRICK OF BARA HAZARI AND TESTED IN UNIVERSAL TESTING MACHINE

TABLE 2. PHYSICAL PROPERTIES OF OLD BAKED CLAY BRICKS

\begin{tabular}{|c|c|c|c|c|c|c|}
\hline Site & $\begin{array}{c}\text { Apparent Density } \\
\left(\mathrm{kg} / \mathrm{m}^{3}\right)\end{array}$ & $\begin{array}{c}\text { Compressive Strength } \\
\left(\mathrm{N} / \mathrm{mm}^{2}\right)\end{array}$ & $\begin{array}{c}\text { Tensile Strength } \\
\left(\mathrm{N} / \mathrm{mm}^{2}\right)\end{array}$ & $\begin{array}{c}\text { Modulus of Rupture } \\
\left(\mathrm{N} / \mathrm{mm}^{2}\right)\end{array}$ & $\begin{array}{c}\text { Absorbed Water } \\
(\%)\end{array}$ & $\begin{array}{c}\text { Effect of } \\
\text { Weathering }\end{array}$ \\
\hline Lanjari & $1455-1680$ & 9 & 0.8 & 4.3 & 17 & Moderately Affected \\
\hline Jarkus & $1500-1660$ & 12 & 1.6 & 3.8 & 22 & Very Slightly Affected \\
\hline Daim Pir & $1700-1820$ & 14 & 1.6 & 4.5 & 19 & \\
\hline Bara Hazari & $1400-1830$ & 19 & 2.2 & 5.9 & 20 & \multirow{2}{*}{ Not Affected } \\
\hline Jadam Pir & $1750-1800$ & 16 & 1.8 & 4.4 & 16 & \\
\hline Ghoghat & $1640-1750$ & 16 & 1.6 & 4.2 & 20 & \\
\hline
\end{tabular}

Mehran University Research Journal of Engineering \& Technology, Volume 35, No. 3, July, 2016 [p-ISSN: 0254-7821, e-ISSN: 2413-7219] 
[25]. The comparison shows that the tensile strength values of the old baked clay bricks taken from two sites (Bara Hazariand Jadam Pir) are higher than the corresponding values of modern bricks. Whereas, the tensile strength values of the four sites (Lanjari, Jarkus, Daim Pir and Ghoghat) are less than the corresponding values of the modern bricks.

The values of modulus of rupture of the baked clay bricks of Indus valley civilization of tenth century are more than the corresponding values of baked clay bricks of present age, as reported by Ansari [25] and they are found to be weather resistant [26].

\section{CONCLUSION}

Old baked clay bricks of Indus valley civilization of tenth century were tested for determination of their physical properties. These properties were compared to the corresponding values of the baked clay bricks of same era. The results of compressive strength, modulus of rupture and apparent density are in agreement with the corresponding values of old bricks of same era. This study shows that bricks collected from the banks of river Indus in district Sanghar are found to be weather resistant according to ASTM standards.

\section{ACKNOWLEDGEMENT}

The authors would like to thank Quaid-e-Awam University of Engineering, Science \& Technology, Nawabshah, and Mehran University of Engineering \& Technology, Jamshoro, Pakistan, for their support to conduct this research study.

\section{REFERENCES}

[1] Dan, M.B., Pøikryl, R., and Török, Á. (Editors), "Materials, Technologies and Practice in Historic Heritage Structures”, Springer, 2010.

[2] Riccardi, M.P., Messiga, B., and Duminuco, P., “An Approach to the Dynamics of Clay Firing", Applied Clay Science, Volume 15, No. 3, pp. 393-409, 1999.
[3] Barsoum, M., and Barsoum, M.W., "Fundamentals of Ceramics", CRC Press, 2002.

[4] Karaman, S., Ersahin, S., and Gunal, H., "Firing Temperature and Firing Time Influence on Mechanical and Physical Properties of Clay Bricks", Journal of Scientific \& Industrial Research, Volume 65, No. 2, pp. 153-159, 2006.

[5] Gunal, H., and Gokalp, Z., "Variation of Clay Brick Colors and Mechanical Strength as Affected by Different Firing Temperatures", Scientific Research and Essays, Volume 7, No. 49, pp. 4208-4212, 2012.

[6] Monteiro, S.N., and Vieira, C.M.F., "Influence of Firing Temperature on the Ceramic Properties of Clays from Campos Dos Goytacazes, Brazil", Applied Clay Science, Volume 27, No. 3, pp. 229-234, 2004.

[7] Carretero, M.I., Dondi, M., Fabbri, B., and Raimondo, M., "The Influence of Shaping and Firing Technology on Ceramic Properties of Calcareous and Non-Calcareous Illitic-Chloritic Clays", Applied Clay Science, Volume 20, No. 6, pp. 301-306, 2002.

[8] Baccour, H., Medhioub, M., Jamoussi, F., and Mhiri, T., "Influence of Firing Temperature on the Ceramic Properties of Triassic Clays from Tunisia", Journal of Materials Processing Technology, Volume 209, No. 6, pp. 2812-2817, 2009.

[9] Lee, V.G., and Yeh, T.H., "Sintering Effects on the Development of Mechanical Properties of Fired Clay Ceramics", Materials Science and Engineering-A, Volume 485, No. 1, pp. 5-13, 2008.

[10] Triantafillou, T.C., and Fardis, M.N., "Strengthening of Historic Masonry Structures with Composite Materials", Materials and Structures, Volume 30, No. 8, pp. 486-496, 1997.

[11] Fitch, J.M., "Historic Preservation: Curatorial Management of the Built World", University of Virginia Press, 1990.

[12] Benhamou, F., "Is Increased Public Spending for the Preservation of Historic Monuments Inevitable? The French Case", Journal of Cultural Economics, Volume 20, No. 2, pp. 115-131, 1996. 
[13] Atamturktur, S., and Laman, J.A., "Finite Element Model Correlation and Calibration of Historic Masonry Monuments: Review", The Structural Design of Tall and Special Buildings, Volume 21, No. 2, pp. 96-113, 2012.

[14] Feilden, B., "Conservation of Historic Buildings", Routledge, 2007.

[15] Modena, C., "Criteria for Cautious Repair of Historic Buildings: Evaluation and Strengthening of Existing Masonry Structures”, RILEM, pp. 25-42, Paris, 1997.

[16] Baker, D., and Chitty, G. (Editors), "Managing Historic Sites and Buildings: Reconciling Presentation and Preservation”, Routledge, 2013.

[17] DeBuergo Ballester, M.A., and González, R.F., "Characterizing the Construction Materials of a Historic Building and Evaluating Possible Preservation Treatments for Restoration Purposes", Geological Society, Special Publications, Volume 205, No. 1, pp. 241-254, London, 2002.

[18] Kumar, P., and Imam, B., "Footprints of Air Pollution and Changing Environment on the Sustainability of Built Infrastructure", Science of the Total Environment, Volume 444, pp. 85-101, 2013.

[19] Prasertsan, S., and Theppaya, T., “A Study Toward Energy Saving in Brick Making: Part-1-Key Parameters for Energy Saving”, International Energy Journal, Volume 17, No. 2, 145-156, 1995.
[20] Bhatnagar, J.M., and Goel, R.K., "Thermal Changes in Clay Products from Alluvial Deposits of the IndoGangetic Plains", Construction and Building Materials, Volume 16, No. 2, pp. 113-122, 2002.

[21] Cunningham, A., "The Ancient Geography of India", Genesis Publishing Pvt. Ltd., 1975.

[22] Marzahn, G.A., Jahnel, R., and Tue, N.V., "Finite Element Analysis of Two Ancient Groined Masonry Vaults", 3th International Conference on Brick/block Masonry, pp. 147-156, Amsterdam, Netherlands, 2004.

[23] Maierhofer, C., Leipold, S., Schaurich, D., Binda, L., and Saisi, A., "Determination of the Moisture Distribution in the Outside Walls of the S. Maria Rossa using Radar", Proceedings of 7 th International Conference on GPR, pp. 509-514,1998.

[24] López-Arce, P., Garcia-Guinea, J., Gracia, M., and Obis, J., "Bricks in Historical Buildings of Toledo City: Characterization and Restoration", Materials Characterization, Volume 50, No. 1, pp. 59-68, 2003.

[25] Ansari, A.A., "Experimental Study of the Behaviour of Pre-Perforated Post-Reinforced Baked Clay Panels of Beams", Ph.D. Thesis, Department of Civil Engineering, Quaid-e-Awam University of Engineering, Science \& Technology, Nawabshah, Pakistan, 2008.

[26] ASTM C62-00, "Standard Specification for Building Brick (Solid Masonry Units Made from Clay or Shale)", American Society for Testing and Materials, West Conshohocken, PA, USA, 2000. 